\title{
ANALISIS PERILAKU KONSUMEN TERHADAP SAYURAN SEGAR DI HYPERMART LOMBOK EPICENTRUM MALL KOTA MATARAM
}

\section{ANALYSIS OF CONSUMER BEHAVIOR OF FRESH VEGETABLES IN HYPERMART LOMBOK EPICENTRUM MALL CITY OF MATARAM}

\author{
Shafirah Adilah, Sri Maryati, dan Hayati \\ Program Studi Agribisnis Fakultas Pertanian Unram
}

\begin{abstract}
ABSTRAK
Tujuan penelitian ini adalah: 1) Untuk mengetahui perilaku konsumen dalam membeli sayuran segar berdasarkan atribut sayuran segar, 2) Untuk mengetahui proses pengambilan keputusan konsumen dalam membeli sayuran segar di Hypermart Lombok Epicentrum Mall. Metode yang digunakan adalah metode deskriptif dan pengumpulan data dilakukan dengan teknik survey dan wawancara, lokasi penelitian di Hypermart Lombok Epicentrum Mall Kota Mataram. Jumlah sampel sebanyak 5\% dari rata-rata pengunjung Hypermart per hari yang ditentukan secara "Accidental Sampling”. Data yang diperoleh dianalisis dengan cara: Analisis Multiatribut Fishbein model TRA, dan Analisis Deskriptif. Hasil penelitian menunjukkan bahwa: 1) Perilaku konsumen terhadap produk sayuran segar berada pada perilaku yang netral, dilihat dari sikap dan norma subyektif konsumen, perilaku konsumen tersebut dipengaruhi oleh beberapa atribut yang secara berturut-turut sebagai berikut: kemasan/packaging, kebersihan, kecerahan warna, kesegaran, harga dan ketersediaan sayuran. 2) Proses pengambilan keputusan pembelian sayuran segar dimulai dengan tahap pengenalan masalah, yaitu karena persediaan sayuran sudah habis, informasi penjualan sayuran segar didapatkan konsumen langsung dari Hypermart, pada tahap evaluasi alternatif konsumen lebih mempertimbangkan ketersediaan sayuran, lalu pada tahap keputusan pembelian, konsumen memutuskan untuk berbelanja sayuran segar di Hypermart karena kualitas sayuran yang bagus. Pada tahap pasca pembelian sebagian besar konsumen merasa puas terhadap pembelian produk sayuran segar yang dilakukan dan akan melakukan pengulangan pembelian produk sayuran segar di Hypermart Lombok Epicentrum Mall.
\end{abstract}

Kata kunci: Perilaku Konsumen, Sayuran Segar 


\begin{abstract}
The purpose of this research are: 1) To know consumer behavior in purchasing fresh vegetables based on attributes of fresh vegetables, 2) To know the process consumer decision in purchasing fresh vegetables in Hypermart Lombok Epicentrum Mall. The method is descriptive and data taken by surveying and interviewing. The location of research is in Hypermart Lombok Epicentrum Mall Mataram. Total samples as much $5 \%$ of the average daily hypermart visitors are determined by "Accidental Sampling". Collected data are analyzed by: Fishbein's Multiattribute analysis TRA model, and Descriptive Analysis. The results showed that: 1) Consumer behavior on fresh vegetables is in the behavior of neutral behavior, it can be judged from the attitude and subjective norm which is in the neutral score interval, that consumer behavior is influenced by some attribute, namely: packaging, purity, color, freshness, price and avaibility of vegetables. 2) The process of consumer decision in purchasing fresh vegetables is started with the recognizing phase of the problem, because the supply of vegetables is out of stock, fresh vegetables sales information is obtained directly by consumers from Hypermart, in alternative evaluation phase, consumers will consider more about the stock of vegetables, then in purchasing decision phase,consumen decide to buy fresh vegetables in Hypermart because of the good quality of vegetables. Also, In the alternative evaluation and purchasing decision phase, consumers take some consideration on supporting factors that are due to the convenience of shopping and good service. In the post-purchasing phase, most of Hypermart consumers are satisfied with the purchase of fresh vegetables product and will repeat the purchase of fresh vegetables in Hypermart Lombok Epicentrum Mall.
\end{abstract}

\title{
Keywords: Consumer Behavior, Fresh Vegetables
}

\section{PENDAHULUAN}

Kebutuhan manusia akan sayuran dibarengi dengan maraknya penjualan sayuran segar di berbagai retail modern. Masyarakat saat ini cenderung menyukai berbelanja di retail modern seperti hypermarket, supermarket, maupun minimarket sehingga tidak heran berbagai jenis retail pun sudah menjangkau ke daerah-daerah, salah satunya yaitu Pulau Lombok.

Hingga tahun 2017 jumlah retail modern yang dibangun sudah mencapai 234 unit (Bul, 2017). Beberapa diantaranya yaitu Hero supermarket, MGM supermarket, Giant Ekspress, Giant Extra, Smart Club, Carrefour, Indomaret, Alfamart, dan hadirnya jenis pasar modern hypermarket yaitu Hypermart Lombok Epicentrum Mall yang menyediakan beraneka macam produk kebutuhan sehari-hari seperti 
perlengkapan rumah tangga, pakaian, makanan ringan, alat tulis, gadget, makanan beku, hingga produk segar seperti buah-buahan dan sayur-sayuran segar.

Dalam membeli, setiap konsumen memiliki perilaku, kebutuhan dan selera yang berbeda. Perilaku konsumen inilah yang mempengaruhi seseorang dalam mengambil keputusan, dalam mengambil keputusan seseorang akan melalui beberapa tahapan terlebih dahulu, yaitu tahap pengenalan masalah, pencarian informasi, evaluasi alternatif, keputusan pembelian, dan perilaku pasca pembelian (Kotler, 2002).

Berdasarkan uraian tersebut maka perlu dilakukan peneliatan mengenai "Analisis Perilaku Konsumen Terhadap Sayuran Segar di Hypermart Lombok Epicentrum Mall Kota Mataram”, dengan tujuan: 1) Untuk mengetahui perilaku konsumen dalam membeli sayuran segar berdasarkan atribut sayuran segar, 2) Untuk mengetahui proses pengambilan keputusan konsumen dalam membeli sayuran segar.

\section{METODE PENELITIAN}

Metode yang digunakan adalah metode deskriptif dan pengumpulan data dilakukan dengan teknik survey dan wawancara. Penelitian ini dilaksanakan di Hypermart Lombok Epicentrum Mall Kota Mataram. Jumlah sampel sebanyak 5\% dari rata-rata pengunjung Hypermart per hari yang ditentukan secara "Accidental Sampling”. Perilaku konsumen dianalisis menggunakan multiatribut fishbein model TRA dengan 2 variabel yaitu variabel sikap dan norma subyektif. Untuk mengukur keputusan pembelian menggunakan analisis deskriptif dengan variabel pengenalan masalah, pencarian informasi, evaluasi alternatif, keputusan pembelian dan perilaku pasca pembelian.

\section{HASIL DAN PEMBAHASAN}

\section{Gambaran Umum Konsumen Sayuran Segar di Hypermart Lombok Epicentrum Mall Kota Mataram}

Penelitian terhadap konsumen sayuran segar dilakukan pada bulan Desember 2017 mulai dari pukul 11.00 sampai dengan 21.00 konsumen sayuran segar terdiri dari perempuan $(87,67 \%)$ dan laki laki $(12,33 \%)$ dengan rentang usia dari 20 hingga 60 tahun, konsumen sayuran segar berbelanja berbagai jenis sayuran karena berbagai alasan, jawaban konsumen secara umum menyatakan bahwa kebersihan (higenis) dan kenyamanan berbelanja menjadi alasan konsumen untuk berbelanja sayuran segar di Hypermart dengan persentase tertinggi sebesar 50,68\%. Frekuensi pembelian sayuran konsumen di Hypermart tertinggi yaitu dengan jumlah konsumen 26 orang atau $35,62 \%$ dengan frekuensi pembelian sayuran segar sebanyak seminggu sekali. Pentingnya sayuran bagi tubuh, membuat konsumen selalu membeli sayuran untuk memenuhi kebutuhannya sehari-hari, dalam sebulan pengeluaran konsumen untuk 
membeli sayuran segar beragam, tergantung kebutuhan konsumen akan sayuran segar itu sendiri, konsumen terbanyak yaitu 19 orang atau 26,03\% mengeluarkan Rp.200.000 per bulan untuk memenuhi kebutuhan sayurannya.

\section{Karakteristik Responden}

Karakteristik responden dalam penelitian ini meliputi jenis kelamin, usia, status pernikahan, jumlah anggota keluarga, pendidikan terakhir, pendapatan per bulan, dan pekerjaan

Sumarwan (2004) menjelaskan bahwa sebaran usia konsumen dikelompokkan menjadi enam bagian berdasarkan skala usia yaitu remaja lanjut, dewasa awal, dewasa lanjut, paruh baya, tua dan lanjut usia. Usia responden di Hypermart berkisar antara konsumen berusia dewasa (21-35 tahun) dan paruh baya (36-50 tahun) yang dimana konsumen dalam membeli sayuran segar sudah memiliki pertimbangan tertentu dalam mengambil keputusan dan mengerti tentang sayuran yang akan dipilih.

Status pernikahan responden didominasi oleh konsumen yang sudah menikah dengan persentase $82,19 \%$ status pernikahan mempengaruhi perilaku serta keputusan dalam belanja baik itu dalam hal kualitas, kuantitas dan jenis sayuran yang dibeli.

Jumlah anggota keluarga mempengaruhi perilaku dan proses keputusan pembelian. Jumlah anggota keluarga terbanyak yaitu pada kisaran anggota keluarga 14 orang dengan persentase $65,75 \%$ dan yang terkecil yaitu dengan jumlah anggota keluarga $\geq 8$ orang dengan persentase $1,37 \%$ hal ini menunjukkan rata-rata responden sayuran segar di Hypermart Lombok Epicentrum Mall tergolong keluarga kecil. Hal ini mengacu pada pendapat Suyono (2003), yaitu: 1) Keluarga kecil (1-4 orang), 2) Keluarga sedang (5-7 orang), 3) Keluarga besar ( $\geq 8$ orang)

Tingkat pendidikan terakhir responden didominasi oleh lulusan perguaruan tinggi (Strata 1 dan Diploma) yaitu sebanyak 47 orang atau 64,38\%, dan yang terendah yaitu dengan tingkat pendidikan akhir pasca sarjana dengan jumlah 11 orang atau $15,07 \%$.

Tingkat pendapatan konsumen yang membeli sayuran segar di pasar modern Hypermart Lombok Epicentrum Mall adalah rata-rata pendapatan keluarga dalam satu bulan. Pendapatan perbulan konsumen didominasi oleh konsumen dengan pendapatan perbulan di atas Rp. 5.000.000 yaitu sebanyak 39 konsumen atau 53\%.

Pekerjaan yang dilakukan oleh konsumen sangat mempengaruhi gaya hidupnya (Engel et al, 1994). pekerjaan responden sayuran segar didominasi oleh konsumen yang bekerja sebagai wiraswasta yakni sebanyak 25 konsumen atau 34,25\%, dan mayoritas kedua yaitu sebanyak 23 konsumen bekerja sebagai PNS. 


\section{Perilaku Konsumen Terhadap Sayuran Segar di Hypermart Lombok Epicentrum Mall}

Tabel 1. Hasil Perhitungan Perilaku Konsumen terhadap sayuran segar di Hypermart Lombok Epicentrum Mall, 2018

\begin{tabular}{llrl}
\hline No & Komponen & Nilai & Interval Skor \\
\hline 1 & Perilaku Konsumen & 3 & Netral \\
2 & Sikap (Ab) & 83,284 & Netral \\
& $\bullet \quad$ Keyakinan (bi) & 3,76 & Positif \\
& $\bullet \quad$ Evaluasi (ei) & 3,67 & Positif \\
3 & Norma Subjektif (SN) & 24,221 & Netral \\
& $\bullet \quad$ Keyakinan Normatif (NBj) & 3,46 & Positif \\
& $\bullet \quad$ Motivasi Mengikuti (MCj) & 3,49 & Positif \\
4 & Bobot Empiris & 0,52 & \\
& $\bullet \quad$ Bobot Empiris Sikap (W1) & 0,48 & \\
\multicolumn{2}{l}{ Sumber: Data Primer diolah, 2018 } & &
\end{tabular}

Berdasarkan Tabel 1 menunjukkan bahwa secara parsial rata-rata nilai keyakinan dan evaluasi masing-masing sebesar 3,76 dan 3,67 yang keduanya berada pada interval skor positif, secara bersama-sama menghasilkan sikap total sebesar 83,284 yang berada pada interval skor netral. Begitu juga dengan perhitungan Norma Subyektif, secara parsial rata-rata nilai keyakinan normatif dan motivasi sebesar 3,46 dan 3,49 yang berada pada interval skor positif, secara bersama-sama menghasilkan norma subjektif sebesar 24,221 yang berada pada interval skor netral. Nilai pengaruh relatif sikap dan pengaruh relatif norma subyektif yaitu sebesar 0,52 dan 0,48 yang diperoleh dari perhitungan bobot empiris GMAb dan GMSN yang menunjukkan bahwa pembelian konsumen lebih didominasi oleh diri sendiri dibandingkan orang lain. Selanjutnya Perilaku konsumen bernilai 3 yang berada pada interval perilaku yang netral.

\section{Sikap Konsumen Terhadap Sayuran Segar di Hypermart Lombok Epicentrum Mall}

Hasil penelitian menunjukkan sikap konsumen terhadap produk sayuran segar di hypermart Lombok Epicentrum Mall bernilai 83,24 dalam arti konsumen memiliki sikap netral terhadap sayuran segar di hypermart Lombok Epicentrum Mall didasarkan pada variabel keyakinan dan variabel evaluasi konsumen terhadap atribut yang diteliti secara keseluruhan.

Total sikap konsumen diperoleh dari nilai atribut-atribut sayuran segar yang secara berturut-turut sebagai berikut:

1) Atribut kemasan/packaging merupakan atribut yang memiliki nilai tertinggi dalam penilaian sikap konsumen untuk membeli sayuran segar di hypermart dengan nilai sebesar 16,33 yang menunjukkan bahwa konsumen merasa kemasan sayuran segar yang dijual tergolong bagus dan merupakan hal yang penting bagi konsumen. 
2) Atribut kebersihan sayuran bernilai 15,72 yang menunjukkan bahwa konsumen sayuran segar menilai bahwa kebersihan sayuran yang dijual terjaga dan tidak ada kotoran yang menempel pada sayuran.

3) Atribut kecerahan warna sayuran bernilai 13,83 yang dinilai konsumen baik, sehingga membuat konsumen tertarik untuk melihat-lihat di display toko.

4) Atribut kesegaran sayuran dengan nilai 13,68 yang dinilai konsumen bahwa sayuran yang di jual tergolong segar, meskipun terkadang ada beberapa jenis sayuran yang dikatakan konsumen sudah layu karena sudah beberapa hari berada di display.

5) Atribut harga sayuran dengan nilai 12,83 yang dinilai konsumen harga sayuran yang dijual masih terjangkau dan harga yang ditawarkan sesuai dengan kualitas sayuran yang dijual.

6) Atribut ketersediaan sayuran dengan nilai 10,90 yang merupakan nilai terendah dari atribut yang lain, konsumen menyatakan bahwa pada hari-hari tertentu sayuran yang diinginkan oleh konsumen tidak tersedia, sehingga konsumen mencari jenis sayuran lain atau tidak jadi berbelanja sayuran.

Sikap konsumen akan atribut ini membuat konsumen mengambil keputusan atas kemauan sendiri tanpa ada pengaruh dari orang lain dalam hal ini adalah keluarga dan teman. Berikut hasil perhitungan variabel keyakinan dan evaluasi.

\section{Keyakinan Konsumen Terhadap Atribut Sayuran Segar di Hypermart Lombok Epicentrum Mall}

Berdasarkan hasil penelitian total rata-rata keyakinan secara keseluruhan atribut-atribut pada sayuran segar yang diteliti bernilai 3,76 menunjukkan nilai yang berada pada interval skor positif. Hal ini menunjukkan bahwa konsumen memiliki keyakinan yang baik terhadap semua atribut sebelum konsumen membeli produk tersebut. Rata-rata total keyakinan tersebut diperoleh dari pernyataan konsumen mengenai beberapa atribut sayuran yang ditanyakan sebagai berikut :

1) Harga sayuran terjangkau dengan rata-rata 3,62 yang berada pada posisi positif, hal ini menunjukkan bahwa konsumen sayuran meyakini bahwa harga yang ditawarkan masih tergolong baik.

2) Kesegaran sayuran terjaga dengan rata-rata 3,75 yang juga berada pada posisi positif, hal ini menunjukkan bahwa konsumen meyakini bahwa sayuran yang dijual memiliki kesegaran yang terjaga serta kualitas yang bagus karena sayuran dikemas dengan baik dan disimpan di tempat yang suhunya sudah diatur sehingga sayuran tetap terjaga kesegarannya.

3) Kecerahan warna sayuran baik dengan rata-rata 3,79, yang terletak pada posisi positif yang berarti bahwa, konsumen meyakini kecerahan warna sayuran yang dijual baik dan menarik perhatian konsumen.

4) Kebersihan sayuran yang terjaga dengan rata-rata 4,0, nilai tersebut terletak pada kisaran positif yang berarti konsumen meyakini sayuran yang dijual memiliki kebersihan yang terjaga karena didukung dengan fasilitas yang memadai, sehingga sayuran yang dijual tetap higenis.

5) Ketersediaan sayuran yang selalu ada, dengan rata-rata 3,36 yang berada pada posisi kisaran netral dengan artian konsumen masih memiliki keyakinan yang lumayan baik terhadap atribut tersebut, konsumen meyakini bahwa sayuran yang 
akan mereka beli tetap tersedia, karena hypermart selalu menyediakan sayuran dari pemasok-pemasok sayuran.

6) Kemasan/packaging sayuran segar yang bagus, dengan rata-rata 4,08 yang berada pada kisaran positif, dengan artian konsumen meyakini bahwa pasar modern pasti mengemas produk-produk yang dijual dengan baik agar kualitas produk dapat terjaga.

\section{Evaluasi Konsumen Terhadap Sayuran Segar di Hypermart Lombok Epicentrum Mall}

Berdasarkan hasil penelitian diperoleh informasi bahwa total rata-rata evaluasi secara keseluruhan atribut-atribut pada sayuran segar yang diteliti bernilai 3,67 menunjukkan nilai yang berada pada interval skor positif. Hal ini menunjukkan bahwa konsumen memiliki evaluasi yang baik terhadap semua atribut setelah konsumen membeli produk tersebut. Rata-rata total evaluasi (ei) tersebut diperoleh dari pernyataan konsumen mengenai beberapa atribut sayuran yang ditanyakan sebagai berikut :

1) Atribut harga sayuran terjangkau dengan rata-rata sebesar 3,55 yang berada pada posisi positif, hal ini menunjukkan bahwa harga tergolong masih bisa dijangkau oleh konsumen, dan harga yang ditawarkan juga sesuai dengan kualitas sayuran yang dijual.

2) Kesegaran sayuran yang terjaga dengan rata-rata sebesar 3,64 yang berada pada posisi positif. Konsumen menyatakan bahwa kesegaran sayuran yang dijual bagus dan masih sesuai dengan keyakinan mereka, kesegaran sayuran yang terjaga penting bagi konsumen karena kesegaran sayuran akan mempengaruhi rasa serta tekstur dari sayuran.

3) Atribut kecerahan warna yang baik dengan rata-rata 3,64 yang berada pada posisi positif yang menunjukkan bahwa kecerahan sayuran yang dijual masih dinilai baik oleh konsumen. Kecerahan warna yang baik akan menarik perhatian konsumen untuk melihat-lihat ke display toko saat berjalan-jalan di Hypermart.

4) Atribut selanjutnya yaitu kebersihan sayuran yang terjaga dengan rata-rata sebesar 3,92 yang berada pada posisi positif. Hal ini menunjukkan bahwa kebersihan sayuran yang dijual dinilai baik oleh konsumen, kebersihan sayuran menunjukkan kualitas dari sayuran yang dijual.

5) Atribut ketersediaan sayuran yang selalu ada dengan rata-rata sebesar 3,25 yang berada pada posisi kisaran netral dengan artian nilai tersebut dianggap biasa saja oleh konsumen. Beberapa konsmen menyatakan bahwa sayuran yang dijual di Hypermart terkadang tidak tersedia pada hari-hari tertentu karena persediaan yang sudah habis dan tidak langsung di stok.

6) Selanjutnya atribut sayuran kemasan/packaging yang bagus dengan rata-rata 4,00 yang berada pada kisaran postif. Hal ini menunjukan bahwa kemasan/ packaging yang bagus membuat konsumen tertarik untuk melihat-lihat terlebih dahulu sayuran di display toko. Dengan adanya kemasan, konsumen mempercayai bahwa sayuran yang dijual terbebas dari kotoran serta memiliki kualitas yang tinggi. 


\section{Norma Subyektif Konsumen Terhadap Sayuran Segar di Hypermart Lombok Epicentrum Mall}

Norma Subyektif konsumen bernilai 24,22 yang berada pada interval skor Netral dalam arti referen (teman dan keluarga) biasa saja dalam mempengaruhi konsumen terhadap pengambilan keputusan. Keputusan pembelian sayuran segar didasarkan pada variabel keyakinan Normatif dan Variabel Motivasi sebagai pengaruh eksternal selain kemauan dari diri responden. Berikut hasil perhitungan variabel Keyakinan Normatif dan Variabel Motivasi

\section{Keyakinan Normatif Konsumen}

Keyakinan normatif konsumen menunjukkan hasil yang positif baik itu dari keluarga dan teman, namun jika dilihat dari rata-rata norma subyektif tersebut, respon keluarga lebih baik dibandingkan dengan teman, dilihat dari rata-rata keluarga sebesar 3,53 lebih besar dibandingkan nilai dari teman, yaitu sebesar 3,40.

\section{Motivasi Konsumen}

Motivasi konsumen menunjukkan hasil yang positif, baik itu teman maupun keluarga dalam arti konsumen mau mengikuti anjuran yang ditawarkan oleh referen. Namun jika dilihat dari rata-rata motivasi tersebut. responden lebih cenderung mengikuti keinginan keluarga untuk membeli dibandingkan teman-temannya dilihat dari rata-rata nilai keluarga sebesar 3,58 lebih besar dibandingkan nilai referen dari teman yaitu sebesar 3,41.

\section{Analisis Perilaku Konsumen Terhadap Sayuran Segar di Hypermart Lombok Epicentrum Mall}

Berdasarkan hasil perhitungan nilai sikap, norma subyektif, hingga perhitungan bobot empiris pengaruh relatif komponen maka perilaku konsumen sesuai dengan TRA (The Theory of Reasoned Action) menunjukkan bahwa nilai pengaruh relatif sikap lebih besar dari pengaruh relatif norma subyektif yang berarti keputusan untuk membeli sayuran segar di Hypermart Lombok Epicentrum Mall lebih atas keinginan sendiri walaupun pengaruh eksternal tetap mempengaruhi dalam perilaku pembelian. Perilaku Konsumen bernilai 3 yang berada pada interval skor netral, sehingga dapat dikatakan bahwa konsumen mempunyai perilaku pembelian yang netral atau biasa saja untuk berbelanja sayuran segar di Hypermart Lombok Epicentrum Mall.

\section{Proses Pengambilan Keputusan Konsumen}

Secara rinci konsumen yang membeli sayuran segar di Pasar Modern Hypermart Lombok Epicentrum Mall menentukan keputusan pembelian melewati beberapa tahapan, yaitu tahapan pengenalan masalah, pencarian informasi, evaluasi alternatif, keputusan pembelian, dan perilaku pasca pembelian.

\section{Pengenalan Masalah}

Pada tahap pengenalan masalah persentase tertinggi sebesar $58,90 \%$ yaitu karena adanya stimuli dari dalam diri konsumen untuk memenuhi kebutuhannya yaitu karena persedian sayuran sudah habis, dan pengenalan masalah tertinggi selanjutnya dengan persentase sebesar $35,62 \%$ yaitu karena adanya stimuli dari luar dalam hal ini konsumen tertarik membeli saat melihat di display toko. 


\section{Pencarian Informasi}

Tahapan selanjutnya yaitu pencarian informasi mengenai keberadaan sayuran segar yang diinginkan konsumen. Pada tahap ini konsumen sayuran segar mendapat informasi yaitu dengan mendatangi Hypermart secara langsung sebanyak 46 konsumen atau 63,01\%. Hal ini dikarenakan konsumen tersebut sering berbelanja di Hypermart dan melihat penjualan sayuran segar di Hypermart. Selain pencarian informasi dari diri sendiri, untuk bisa menarik perhatian konsumen, Hypermart membuat promosi penjualan produk-produknya yaitu dengan pembuatan katalog, mengiklankan di koran, serta pemberian discount untuk produk-produk tertentu, pengaruh dari promosi penjualan menunjukkan bahwa 43,84\% konsumen menjawab promosi berpengaruh untuk membuat konsumen tertarik melihat-lihat sayuran segar yang dipromosikan.

\section{Evaluasi Alternatif}

Pada tahap evaluasi alternatif ini pertimbangan konsumen yang tertinggi sebanyak 18 konsumen atau 24,65\%, yaitu karena ketersediaan sayuran di Hypermart yang lengkap sehingga dapat memenuhi kebutuhan konsumen akan sayuran. Selain dari faktor evaluasi alternatif itu sendiri, terdapat juga konsumen yang melakukan pertimbangan karena faktor pendukung seperti kenyamanan berbelanja dan dekat dengan tempat tinggal, persentase responden yang mempertimbangkan faktor pendukung kenyamanan berbelanja yaitu 19 responden atau 26,03\%, dan faktor pendukung karena letak Hypermart yang dekat dengan tempat tinggal dengan persentase $12,33 \%$ atau sebanyak 9 responden.

\section{Keputusan Pembelian}

Tahap ini merupakan tahap ketika konsumen benar-benar membeli produk. Berdasarkan hasil penelitian, keputusan pembelian konsumen sebagian besar, yaitu sebanyak 31 konsumen atau sebesar 38,35 \% memutuskan untuk membeli sayuran segar di Hypermart karena kualitas sayuran yang dijual bagus. Sama seperti pada tahap evaluasi alternatif, pada tahap keputusan pembelian terdapat konsumen yang juga mempertimbangkan faktor pendukung, yaitu kenyamanan berbelanja dan pelayanan yang baik dengan persentase sebesar 32,33\% atau sebanyak 24 konsumen dan juga ada konsumen yang hanya mempertimbangkan faktor pendukung kenyamanan berbelanja saja yaitu dengan persentase sebesar 46,58\% atau 34 orang.

\section{Perilaku Pasca Pembelian}

Tahapan ini merupakan tahap terakhir dari proses keputusan pembelian, tahap ini merupakan bagaimana kepuasan konsumen mengenai produk yang telah dibeli dan apakah akan melakukan pengulangan pembelanjaan untuk produk tersebut di tempat yang sama, hasil penelitian menunjukkan bahwa sebagian besar responden merasa puas terhadap pembelian sayuran segar yang dilakukan, yaitu sebanyak 58 konsumen atau 79,45\% sedangkan sebanyak 20,55\% atau 15 konsumen lainnya merasa biasa saja terhadap pembelian yang dilakukan. Kepuasan konsumen ini dikarenakan oleh kepuasan total dari tahapan-tahapan yang telah dilalui oleh konsumen.

Meskipun terdapat responden yang mengatakan biasa saja terhadap pembelian yang dilakukan, namun mereka akan tetap berbelanja sayuran kembali di Hypermart 
Lombok Epicentrum Mall, hal ini dikarenakan mereka berbelanja sayuran yang terkadang tidak terdapat di pasar tradisional serta karena kualitas sayuran yang dijual dinilai baik oleh konsumen.

\section{KESIMPULAN DAN SARAN}

\section{Kesimpulan}

Disimpulkan : 1) Perilaku pembelian konsumen terhadap produk sayuran segar berada pada perilaku yang netral atau biasa saja, dilihat dari sikap dan norma subyektif konsumen yang juga berada pada interval skor netral Perilaku konsumen tersebut dipengaruhi oleh beberapa atribut yang secara berturut-turut sebagai berikut: kemasan/packaging, kebersihan, kecerahan warna, kesegaran, harga dan ketersediaan sayuran. 2) Proses pengambilan keputusan pembelian sayuran segar dimulai dengan tahap pengenalan masalah, yaitu karena persediaan sayuran sudah habis, informasi penjualan sayuran segar didapatkan konsumen langsung dari Hypermart, pada tahap evaluasi alternatif konsumen lebih mempertimbangkan ketersediaan sayuran, lalu pada tahap keputusan pembelian, konsumen memutuskan untuk berbelanja sayuran segar di Hypermart karena kualitas sayuran yang bagus, serta pada tahap evaluasi alternatif dan tahap keputusan pembelian konsumen juga mempertimbangkan faktor pendukung yaitu karena kenyamanan berbelanja dan pelayanan yang baik. Pada tahap pasca pembelian sebagian besar konsumen merasa puas terhadap pembelian produk sayuran segar yang dilakukan dan akan melakukan pengulangan pembelian produk sayuran segar di Hypermart Lombok Epicentrum Mall.

\section{Saran}

Disarankan: 1) Pihak Hypermart Lombok Epicentrum Mall melakukan perbaikan pada atribut yang dinilai kinerjanya masih belum sesuai dengan yang diharapkan oleh konsumen yaitu ketersediaan sayuran. Hypermart harus meningkatkan continuitas persediaan sayuran dalam rangka melayani permintaan konsumen. 2) Hypermart Lombok Epicentrum Mall lebih gencar dalam meningkatkan promosi sayuran segar yang dijual, sehingga pengunjung tidak hanya datang untuk melihat-lihat, tetapi juga datang untuk membeli.

\section{DAFTAR PUSTAKA}

Bul. 2017, Maret 09. Penerbitan Izin Retail Modern Sebaiknya Diawasi Ketat. Suara NTB. Diperoleh: http://www.suarantb.com/news/2017/03/09/26174/penerbitan. izin.retail.modern.sebaiknya.diawasi.ketat. Diakses pada tanggal 07Juni-2017.

Engel, James F, Roger D. Blackwell \& Paul W. Miniard. 1994. Perilaku Konsumen. Jilid ke-1 dan 2. Bina Rupa Aksara: Jakarta.

Kotler, P. 2002. Manajemen Pemasaran. Edisi Milenium. PT Prehallindo: Jakarta.

Sumarwan, U. 2004. Perilaku Konsumen: Teori dan Penerapannya dalam Pemasaran. Ghalia Indonesia: Bogor.

Suyono, H. 2003. Memotong Rantai Kemiskinan. Yayasan Dana Sejahtera Mandiri: Jakarta. 